\title{
ВЛИЯНИЕ НОВЫХ ПРОИЗВОДНЫХ ПИРИМИДИНА - ПОТЕНЦИАЛЬНЫХ ГЕПАТОПРОТЕКТОРОВ НА КЛЕТОЧНЫЙ ЦИКЛ IN VITRO
}

\author{
Г.П. Беляев ${ }^{1}$, А.Б. Выштакалюк ${ }^{1,2}$, А.А. Парфенов ${ }^{1}$, В.Э. Семенов ${ }^{1}$, \\ М.С. Шашин', И.В. Галяметдинова', В.В. Зобов ${ }^{1,2}$ \\ ${ }^{1}$ Институт органической и физической химии им. А.Е. Арбузова КазНЦ РАН, \\ 420088, Россия, Казань, ул. Арбузова, 8. \\ ${ }^{2}$ Казанский (Приволжский) Федеральный университет, \\ 420008, Россия, Казань, ул. Кремлевская, 18.
}

DOI: 10.19163/MedChemRussia2021-2021-420

E-mail: gregoir4@gmail.com

Различные заболевания печени являются причиной смертности около 2 миллионов человек в год [1], что делает поиск эффективных гепатопротекторов актуальной задачей. Изучаемые концентрации новых производных пиримидина Ila, b, представляющих собой «удвоенные» модификации отечественного лекарственного средства Ксимедон I (рис. 1), были взяты по результатам предыдущего исследования цитопротекции этих соединений [2].

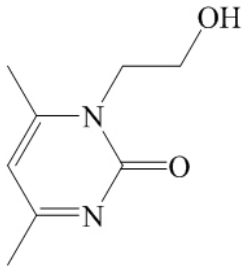

I

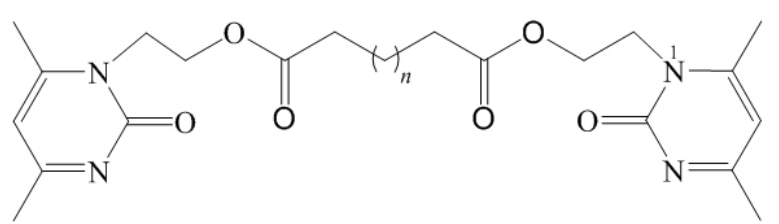

II: $n=0$ (a), 4 (b)

Puc. 1. Структуры Ксимедона (I) и его «сдвоенных» производных IIa, $\boldsymbol{b}$.

Работа была выполнена на клеточной линии нормальных гепатоцитов человека Chang Liver. Клетки инкубировались вместе с изучаемыми веществами в течение 24 часов, затем фиксировались и окрашивались йодидом пропидия, с последующем изучением с помощью проточного цитофлуориметра Guava easy Cyte.

Показано, что соединение Ilb в дозе 0,5 и 0,25 мМ достоверно увеличивает количество клеток в фазе $\mathrm{G}_{2} / \mathrm{M}$, что говорит об активации клеточного деления по сравнению с интактным контролем в 2,33 раза. В случае добавления токсиканта d-ГЛА, замедляющего синтез белка, выяснено, что соединения Ila, b в дозах 0,5 и 0,0625 мМ достоверно ускоряют переход клеток в фазу $\mathrm{G}_{2} / \mathrm{M}$ по сравнению с $d$-ГЛА в 1,6 и 1,4 раз, соответственно.

Таким образом, соединения Ila, b ускоряют деление клеток, чем может объясняться полученный ранее цитопротекторный эффект данных соединений [2].

\section{Литература}

[1] Asrani S. K. et al., J. Hepatology. 2019, 70.1: 151-171.

[2] Выштакалюк, А. Б. и др., Биоорганическая химия. 2020, 46.6: 693-700.

$$
-420-
$$

